\title{
The emergence and transformation of literary space
}

\author{
Reingard Nethersole \\ Dept. of Comparative Literature \\ University of the Witwatersrand \\ JOHANNESBURG
}

\begin{abstract}
"The main theoretical difficulty inherent in the teaching of literature", Paul de Man (1986:29) observed, "is the delimitation of borderlines that circumscribe the literary field by setting it apart from other modes of discourse". Dissatisfied with numerous existing notions as regards literature which are oblivious to the fact that literature depends upon a writer, a book, and a reader, this essay explores spatial denominators in its attempt to define the literary domain. It is argued that while story-telling precedes and succeeds literature, the site of the latter is one which emerged only in modernity and is about to be re-territorialized in the present. The republic of letters or the realm where the text functions as possible world is being replaced by the quarry of stories defining the world as text. Thus the modalities of signification have increased, yet the space of literature has been transformed by technological means changing it into the archive, a place of the past rather than a site of present production.
\end{abstract}

\section{Introduction: The space of stories}

Homer's tale of Odyssey's adventure begins with an invocation of the muse: "Tell me, Muse, of the man of many ways, who was driven/far journeys, after he had sacked Troy's scared citadel. "': and it is through the grace of the muse that "From some point/here goddess, daughter of Zeus" (Homer, 1965:27) the story unfolds. Like in all oral story-telling, the time and place of narration are the hic et nunc of the presence, in which the story-teller, the girot or imbongi, shares with his audience a tale or a praise song which he did not invent and which is older than both. Although part of the Western tradition of literature today, the Homeric text in its written form, like so many others of its kind from all over the world, bears the distinct verbal markers of oral discourse in general, namely the deictic inscriptions 'some pointhere' which in their generality make sense only as indexical gesture of simultaneousness of speaker and listeners. Only when the 
scribe, and especially the printing press, begin to dominate story-telling, the specific places of reading and writing emerge, as they are described, for instance, in J.M. Coetzee's Foe. Foe writes "at his desk", Friday "settled himself on his mat with the slate" and Susan Barton, although initially installed in a rented room, writes as "the woman washed ashore", "from the road" (Coetzee, 1986:146, 147, 99). While these examples provide an ironic insight into various social positions of the writer as the authorial male, patriarchical figure (Foe), the illiterate, colonized emasculated "native" (Friday), and the female "want-to-be" begetter of her own story in a room of her own (Susan), a comparison between Homer's and Coetzee's positioning of narrators highlights the general need for circulating stories on the one hand, and their changing and particular spatialisation on the other. This, it will be argued, affects not only definitions of literature but also the format of telling and signification.

\section{Definitions of the literary object}

It is generally assumed that the literary object exists in itself. Thus the term literature as used in such combinations as English, French, African, or Afrikaans literature, etc. is usually regarded as an a priori given. Literary forms and styles of writing might change but somehow literature has always been there, and it is assumed that it always will be. We apparently know intuitively what separates story-telling as a general occurrence from literature as that which is written, and particularly from Literature with capital $L$ as that which fulfils specific aesthetic criteria. However, our intuition is not only questioned when new voices from different cultural backgrounds demand inclusion in the canon and syllabi of educational institutions as is evident in the often quoted "cultural debate" but it is also put to the test in the teaching of literature. Paul de Man (1986:29) articulates the problem succinctly:

The main theoretical difficulty inherent in the teaching of literature is the delimitation of borderlines that circumscribe the literary field by setting it apart from other modes of discourse. Hence the nervousness which any tampering with the canonical definition of the literary corpus is bound to provoke.

It is interesting that De Man uses spatial denominators, literary field and corpus where other scholars and critics tend to speak of either discursive modalities or formal aspects when seeking to define their object of investigation. But as To-

1 Sce in this connection for instance Johan Geertsema's (1993:109-128) contribution which refers briefly to the continuation of a debate which came to the fore in 1989 (cf. also Nethersole, 1991:239). 
dorov (1990:1-12) has shown, neither the traditional definitions of literature as cathartic or edifying experience nor formal considerations of literariness as suggested by Russian Formalism, or the delimitation of fiction versus non-fiction (essentially evoking the Aristotelian separation between poetry and history) are convincing. Literature, and especially those written works making up the corpus or the 'great tradition' are, indeed, a 'field' in which Literature functions as particular discourse among other discursive systems. This field, or rather the site of Literature, is usually eclipsed when the literary object is either defined merely formally as fiction or purely functionally as edifying. While the former definition overlooks the comparatively short history of Literature in the West, the latter conflates literary representations with all kinds of other ones. Furthermore, both notions of literature, together "with the canonical definition of the literary corpus" imply an author, a book, and a reader. But a look at the other side of the divide between the 'great' and the oral tradition reminds us immediately that the circulation and exchange of stories, poems, plays, and songs is neither dependant upon an author with his or her biography, nor the book and its solitary reader. Although inscriptions together with a multitude of narratives have existed since time immemorial, the notion of Literature prevalent still today owes its emergence only to modernity when the novel became the preferred genre. While the invention of movable type (Gutenberg's printing press) in 1450 had made the book, hitherto hand written, more accessible to the Renaissance, a rapidly increasing readership in the 18th century was responsible for the resounding success of the novel as vehicle for bourgeois self-projection in the 19th century, denigrating the worksong and communal story-telling, the epic as foundation narrative of a people, the legend, the tale, and the mystery play to secondary, folkloristic status fit for the uneducated, peasants, and primitives in the process. Furthermore, the end of the 19th century witnessed the establishment of a specially designated discursive space for literature at institutions of higher learning where the great tradition as opposed to lesser stories was inculcated in the bourgeois mind.

Inasmuch as the novel, without recourse to the dynamics of the voice, to gesture, dance, costume, music and song, is dependant upon the printed book and operates purely on the level of structuring our reading, it not only demands solitary attention from its readers but also idleness. Thus, that marvellous, tongue-in-cheek "Dictionary of Received Ideas" appended by Flaubert to his novel Bouvard and Pécuchet quite rightly defines Literature as an "occupation of idlers" (Flaubert, 1976:315). It is this aspect of Literature, namely the leisurely pursuit of reading as distinct from ritualistic or work specific integration of story and song materials into the life-world which sets the stage for the notion of Literature (especially with capital L) still operative today, as do the following additional five aspects: 
* the transformation of story-telling into novelistic genres as described by Benjamin (1968:83-110) in his "The Storyteller" and Bakhtin (1981:9f.);

* the emergence of a new readership as analysed in detail by Hauser (1962:34-76) and especially Chartier (1989:134-147);

* the concomitant division into 'classical' or highbrow and 'popular' and low brow literature;

* the advent of Baumgarten's and Kant's aesthetic theories which not only create a sub-domain in philosophy, but more importantly, lay the foundation of Anschauungsästhetik which not only prescribes contemplation as the adequate mode for the appreciation of art (Literature) but also elevates the artistic object (in Kant's Critique of Judgement of 1790) to a realm beyond everyday existence where the general and the particular can be synthesised;

* and finally Barthes' (1953:51) and Foucault's (1966:24f.) observations in connection with the birth of a poetic language, a language no longer understood as transparent medium and vehicle for messages, or merely decorative and embellishing the message but rather as autotelic and foregrounding its materiality.

However, the very parameter of literature, conditioned by these five aspects together with the Flaubertian notion of idleness, is increasingly being pushed to its limits by postmodernist forms of expression on the one hand and poststructuralist analyses of discursive systems on the other. Both challenge perceived ideas about literature in as much as they not only tamper with the canonical definition of Literature ${ }^{2}$ but also echo Mallarmé's question (cit. in Blanchot, 1982:42): "Does something like literature exist?". Celebrating the "death of the author" and substituting écriture (writing) for lecture (reading) might be yet another symptom of the demise of the literary corpus, thus putting the teaching of literature into crisis. Yet an investigation into the space of literature will show that while the traditional borderlines of the literary field are being erased its ground is merely being transformed by the electronic media.

2 It is one thing if Roland Barthes (1984) suggests the erasure of such notions as corpus, oeuvre and work, all of which are fundamental operatives in literary studies, wishing to replace these canonical considerations with the notion of ecrifure (writing). It is quite another thing, though, if critics representing feminist, Africanist and all those other interests which have hitherto boen denied entry into the 'great tradition' wish to expand the canon. Although thcy 'tamper' with the established canon, they do not fundamentally question the necessity of its existence as Barthes and the poststructuralists do - something which is also captured by the Mallarmé-quote. 


\section{Spaciality and the literary object}

Arguably, literature is seen foremost as a sonic realization of ideas, as a form of Speech Act (Searle, 1969) or as a verbal structure of differing discursive relations in written form, whereby "in literature the primary category in the chronotope is time" (Bakhtin, 1981:85). Thus the temporal is usually privileged, particularly since speech as phonological occurrence unfolds in time, and even the dominance of graphism in writing addressing itself to the eye rather than the ear is not often explored from a spatial perspective. ${ }^{3}$ Yet, it is not only the site of the narrator as shown briefly in the above-mentioned examples which inscribes itself differently under different historical conditions, but it is also the domain of the author, the book and the reader in which literature is mapped as spatial rather than temporal entity. Speaking about the 'literary corpus', for instance, or metaphorically about the 'depth' of a work indicates spatial considerations as much as the following exclamation by Nietzsche (1980:279): "Never have I felt so much at home in a book, and in $m y$ home ...", an observation shared by many avid readers. The book, after all, does not only occupy space on the library shelf but also in our lives. Montaigne in his essay "Of Books" (1928:92-108) describes this tactile quality of the relationship between the reader and the book, as does Benjamin almost four hundred years later when he unpacks his library: "Property and possession belong to the tactile sphere" (Benjamin, 1968:63). It is this sphere, defined both by the social space of the leisured classes and bourgeois values, and the traversing of inscribed and imagined space in the act of reading, which usually escapes literary criticism and theory.

\section{Theoretical parameters}

To be sure, Blanchot speaks already of The Space of Literature (1982) for the purpose of mapping the position of the poet and the place of the poetic word, celebrating solitude as a necessary pre-condition for the existence of both, while Bachelard's famous Poetics of Space (1969) is devoted to an analysis of the psychoanalytic dimensions of certain re-occurring spatial images. However, I shall

3 Although linguistic insight amplify that spatial devices in language together with spatial markers in texts are, in fact, more frequent than temporal ones, it appears as if primacy of spaciality in perception is overlooked in the Westem tradition because of its "phonocentrism" since the days of Plato.

4 However, an increasing interest in spaciality is not only evident in poststructuralist criticism (cf. Nethersole, 1990:59-65) but also in ethnography. How much spatial and tactile concepts actually inform old and accepted terminology in literary studies is evident, for instance, in the term verse, which refers to the digging of furrows, literally suggesting the lay-out of poetical textures as being similar to a field 
propose here, following theoretical insights gleaned from Thom $(1985),{ }^{5}$ Serres $(1982)^{6}$ and especially Lefebvre (1991), a spatial investigation into literature which, will, albeit briefly, illustrate the transformation of the sites once occupied by the writer, the book and the reader into the postmodernist domain of the copywriter, the film director, the script, the postmodern novel, the advertisement and the viewer, voyeur and spectator. To be sure, notions concerning 'space' are used frequently nowadays, but I am not concerned with spatial imagery but literally with the arena in which the above produce and represent a different social practice.

Undoubtedly literature is enmeshed in institutions such as schools and academic disciplines, ${ }^{7}$ in publishers, book-stores, journals, the library and the media in general all of which circumscribe particular spaces. However, if I elide these conduits for messages and relais of meaning production for the time being, then I do so only in order to briefly foreground the type of social space, the domain of activity and the mode of occupying and writing the modern versus the postmodern space. The examples chosen might be seen to be limiting but I believe the positions of the writer, reader, the book and the library to be crucial for mapping the literary field which at present is being re-territorialized by objects, activities and relations which appear to be different.

The French social philosopher, Lefebvre (1991:37f.), offers a particularly valuable theoretical approach to the problem mentioned by De Man at the outset, because "the borderlines that circumscribe the literary field" are no longer merely attributed to discourse but linked to "actual production of space". After emphasizing the need to shift the "object of interest" from "things in space to actual production of space", Lefebvre links social practices with "representations of space" (38) and "representational spaces" (39). While the former are concerned

5 Rene Thom's work thus offers the "postulate, of which modern man is hardly conscious" that "since identity of a thing has its principle in its spatial localisation, all ontology, all semantics necessarily depends on a study of space - geometric or topological" (Thom, 1985:289)

6 Of special interest here is Michel Serres' work (1982:44f.).

7 After all, to speak 'literally' eg. of literature, implies authority, participation in an arena of letters, institutions, educational and government accredited bodies, the media, ctc In short, to speak literally is to speak of the subject of literature in a special way, a way which Derrida, for instance, deconstructs in superb fashion in his $O u i$, a paper delivered at the James Joyce symposium in Frankfurt in 1984 (Derrida, 1992). Also, the non-discursive relationships of and between institutions maintain the identity of a discourse seen as literary. That these relationships together with all forms of representation can be regarded as ideological goes without question. However, it is precisely the actual production of space in which even ideologies become manifest. 
with the establishment of relations between objects and people in represented space, the latter concerns "the loci of passion, of action and of lived situations" (42). And although this distinction is helpful when dealing with the literary object at length, because it allows for a relation between virtual and actual spaces, socalled images on the one hand and verbal and other types of construction on the other, the following few examples focus merely upon representational space both in its actual and written codification. However, their choice is supported by Lefebvre's (1991:46) assumption

that spatial practice, representations of space and representational spaces contribute in different ways to the production of space according to their qualities and attributes, according to the society or mode of production in question, and according to the historical period.

\section{The space of literature}

Thus, gazing upon the literary field as one marked by objects - in our case the book - and by the activities of reading and writing, a different view offers itself of the republic of letters than is usually obtained from literary histories. Thus the corpus of great works, the canon, appears no longer as an unfolding entity tempered with and threatened by poststructuralist attacks on the value of traditions. Instead, the canon simply marks a trajectory on the map of all possible tales and verses which were excluded at the time of the emergence of Literature. Along this arterial high-road of approved texts thus is situated what is called Literature, localized both within the space of the book and that private domain required for appreciating it. Both constitute, if not marginal, then at least reserved spaces conducive to idleness or contemplation, for the book is not only given a special storage place but also reading it demands spatial as well as social separation either in proximity or distance to other spaces and activities. Verbal and visual illustrations provide numerous examples with regard to ways in which books are housed. For instance, Proust (1981:85) has "the lady in pink" ask the narrator's uncle:

"Who or what is Vaulabelle? Is it those gilt books in the little glass case in your drawing-room? You know you promised to lend them to me. I'll take great care of them."

"The little glass case", Benjamin's "shelves" on which he gives his books "their freedom" (Benjamin, 1968:64) or Locke's library in which every book "was carefully marked as his personal property", as Chartier (1989:134) describes, delineate the domain of the book while indicating its importance in relation to possessions. "Ex libris", carrying the name of the owner, used to be pasted inside the front cover of books. In addition to growing ownership, the by now dominant 
habit of silent reading which, according to Chartier (1989:125), had "radically transformed intellectual work" in the 18th century, calls for a private space, separated from the spheres of commerce, social responsibilities and public activities. Paintings and drawings of the time show both male and female readers in repose either in their salon, library or bedroom. While Montaigne's description of his library retreat ${ }^{8}$ where "he engages in the best of the 'three kinds of commerce', that of a man with his books", namely, with himself (Chartier, 1989:134) set the tone for the spatial co-ordinates defining the modern encounter with books, the novelist Samuel Richardson went so far as to build a grotto in his house at North End for the express purpose of reading to his friends.

\subsection{The republic of letters}

Richardson, like many other authors and especially members of the upper-classes had themselves depicted reading either by themselves or in company. And although solitude as expressed for instance in the famous reading passages in Proust's $A$ la recherche du temps perdu (1913-1927, Eng. transl. 1981:89-95) ${ }^{9}$ was not a prerequisite for an encounter with books, privacy was and still is.

8 Montaigne speaks of "this sweet paternal retreat, he has consecrated it to his freedom, tranquillity, and leisure". It is "a little hard to reach and out of the way, for the bencfit of the exercise as much as to keep the crowds away" (Chartier, I989:f.). Chartier continues his quotations from Montaigne by explaining: "The tension between the desire to withdraw from the crowd while at the same time maintaining control over the world is probably symbolic of the absolute liberty made possible by the commerce with books, hence of the possibility of complete self-mastery without constraint or supervision: 'There is my throne. I try to make my authority over it absolute, and to withdraw this one comer from all society, conjugal, filial, and civil.' The hours spent in the library are hours of withdrawal in two senses," continued Chartier (p.136) "withdrawal from the public sphere, from civic responsibility, from the affairs of city and state; and withdrawal from the family, from the household, from the social responsibilities of domestic intimacy. In retreat, the individual is free, master of his time, of his leisure or study."

9 Proust (1981:89) speaks of "lying stretched out on my bed with a book in my hand. My room quivered with the effort to defend its frail, transparent coolness against the aftemoon sun behind its almost closed shutters through which, however, a glcam of daylight had contrived to insinuate its golden wings, remaining motionless in a comer between glass and woodwork, like a butterfly poised upon a flower". ... "Sweet Sunday afternoons bencath the chestnut-tree in the garden at Combray, carefully purged by me of every commonplace incident of my personal existence, which I had replaced with a life of strange adventures and aspirations in a land watered with living streams, you still recall that life to me when I think of you, and you embody it in effect by virtue of having gradually encircled and enclosed it - while I went on with my reading and the heat of the day declined - in the crystalline succession, slowly changing and dappled with foliage, of your silent, sonorous, fragrant, limpid hours." (Proust, 1981 :94ff.) 
Withdrawing to the library or study, to "this one corner from all society, conjugal, filial, and civil" as Montaigne put it (cf. Chartier, 1989:136), not only produced a space for placing the self in touch with himself and the world but also created the very republic of letters as a separate domain distinct from the affairs of state. Thus, the great French Encyclopédie constitutes on the one hand a realm of the spirit and all available knowledge of the time while on the other Diderot, d'Alembert and their collaborators, exchanging ideas in their studies and corresponding with men of letters as far as Russia, can be seen as occupying an adjacent space, both within and in distance to the political sphere of the enlightened despots. In other words, it is in the shadow of the feudal aristocracy, in the actual spaces of the library, the study and the ladies' salons that the site was created from which emerged the bourgeoisie with its enlightened values and middle-class mores. It is in this space, too, where the ideas of the French Revolution, the revolution of the Third Estate or the middle-class was born. To be sure, this separate domain where the author, the book and the reader reign supreme can be maintained only by leisure and at the expense of having the workplace, the shop or the manufacturing site produce enough wealth to support it.

However, this very space of a state within the state still exists today although the republic of letters might have been usurped by educational institutions, publishers and the media; and the men of letters, the Diderots, Popes, Goethes, Rousseauses, Staëls and others whose ideas shaped the world around them have changed into pop-idols, opinion makers, advertisers and market-researchers. Yet, our relation to the book is still marked by the spatial parameters of both, distance to and separation from the actual life-world as well as privacy necessary for the pursuit of reading. Hence, literature occupies a marginal space whose aesthetic delimitation defined as "disinterested appreciation" by Kant or moral upliftment in the wake of Matthew Amold mark it as a distinct territory which, today, is increasingly contested on the level of the book by film and television and in regard to discursive space by postmodernist bricolage. ${ }^{10}$

\section{The transformation of literary space}

It is not so much the literary field, its trajectories and the relations between its objects and activities which are seemingly destroyed or 'deconstructed' by poststructuralist criticism, as is generally assumed, but rather the space occupied by it

10 Having adopted the notion of bricolage from Levi-Strauss' use as metaphor for mythical thought in the first chapter of his book The Savage Mind (1974:21) postmodernism sces in the bricoleur someone who draws from the stock of already existing elements: "In the continual reconstruction from the same materials, it is always earlier ends which are calied upon to play the part of means: the signified changes into the signifying and vice versa." 
is being transformed in a five-fold process. What we are witnessing at the end of the twentieth century, at least in so-called industrialized countries, ${ }^{11}$ is at first, a transformation of the novelistic genre.

* The 'classical', realist novel, so aptly embodying the panoptic view of literature through its omnipotent narrator and its structuration of closure, centring on "the meaning of life", as Benjamin (1968:99) calls it, is changing into the postmodernist 'open', fragmentary text, barely contained by its cover, such as Pynchon's Crying of Lot 49, a travesty of the quest-novel, the Bildungsroman and many other such sub-genres.

* Readership is becoming 'viewership' in the age of television.

* Divisions between high- and low-brow texts are, if not ignored at least broken down by trivial- and pop-materials being included into apparently demanding texts, thus blurring the distinctions characteristic of modernity and especially Modemism.

* It is the aesthetics of pop- and popular culture, siding with communal activities in the workplace and in groups, which is replacing the aesthetics of the 18 th century

* The self-referential text, the "density" of the poetic word (Barthes, 1953:47) and "poetry ... as the splendour and freshness of a dream language", as Barthes called it once (Barthes, 1953:51), are redistributed in television advertisements and on billboards.

\section{The world as text}

The space of the library and the activity of reading are written differently today. Montaigne's library "is round, the only flat side being the part needed for my table and chair: and curving round me it presents at a glance all my books, arranged in five rows of shelves on all sides" (cit. in Chartier, 1989:135). Borges' postmodern library ("The Library of Babel", 1970:78-86) on the contrary, consists of a multitude of hexagonical, ordered but indeterminable spaces, where a "mirror" in the hallway "faithfully duplicates all appearances" (78), and

11 While so-called marginal and peripheral spaces like the former colonies are increasingly finding their own voice in what is usually described as postcolonial literature on the one hand, these very same emerging literatures appear to embrace mainly the earlier mentioned process on the other. However, it would be worthwhile to explore, for instance, the South African literary system in detail in this respect in order to establish any specific relations between what Jameson has called 'late capitalism' and postmodernism 
"inexhaustible stairways" (79) give the impression of infinite space. While Montaigne's library is a retreat, set-off from the household but affording "rich and free views in three directions" (79), thus marking a centre from which to survey the world, Borges' library not only looks in upon itself but is "the universe" (78). Thus, the traditional or 'classical' library marks a secondary domain, distinct from the world, in which the activity of writing and reading constructs the possible worlds residing in books, while "The Library of Babel" views the world as text. Where else the former sees in the encyclopedic accumulation of knowledge about the self and the world the possibility of obtaining meaning, the latter sees only an infinite deferral of meaning, because "the inconceivable middle page" which "would have no reverse" (Borges, 1970:86) is, precisely, inconceivable.

Similarly, a comparison between Proust's first-person narrator and Pynchon's Oedipa reading conveys the difference between "the pursuit of the hero through the pages of my book" (Proust, 1981:94) and the "search among alternate universes" (Pynchon, 1965:70) set into motion by an acronym found on a lavatory wall. In pursuit of signs rather than "consciousness" (Proust, 1981:94) and the transformation of time into space, Oedipa wondered, where "does the paperback I bought at Zapf's get off with its 'Trystero' line? Was there yet another edition, beside the Quarto, Folio, and 'Whitechapel' fragment? (...) She spent nearly an hour more, searching through all the footnotes, finding nothing" (Pynchon, 1965: 70).

Where the modern text and the 18th century novel seek to delimit space, the postmodernist text proliferates space, crossing arbitrarily from one place to another or simply circulates in a timeless universe, scanning bits of information like Oedipa, instead of holding on to the centre which, Proust's narrator feels, the book will reveal. While the former attempts to order an incommensurable universe, the latter rummages through the quarry of a universe always already written. Thus, similar to Pynchon whose female protagonist finds herself in a world of shifting signifiers, Coetzee's Susan Barton finds herself surrounded by ghosts (Coetzee, 1986:132); and while Daniel Defoe sought to create the life and adventure of Robinson Crusoe and The Fortunate Mistress (both of which operate as the pretext in Foe) in the early 17th century, Coetzee's palimpsest of the late 20th century does not explore imaginary spaces but sites of the written. In addition, narrative ordering today is no longer hierarchical and linear but taxonomic, simultaneous, and spatial.

However, despite these differences on the level of representation, the representational spaces of the library and the novel are still the same: and, both the library and the reader still share the same relations in the same space marked by idleness 
and privacy as preconditions for entertainment, enjoyment, thought, selfdiscovery and the pursuit of knowledge. Although today's avant garde text no longer serves the purpose of producing meaning but, instead, questions the meaning set up by past stories, it still remains a textual space, which like the visual space of the television screen, promises those who engage with it a transfer of knowledge, values, and enjoyment.

\section{The space of literature re-territorialized}

In short, the particular representational space delimited by the domains of play, entertainment, self-education and even seduction ${ }^{12}$ as opposed to the work sphere has remained largely unchanged since the time of the emergence of the bourgeoisie. Marked changes in the forms, 'themes' and content of the book, in short those features usually ascribed to postmodemism ${ }^{13}$ might hint at a different conception of space, yet they are still occupying the same "loci of passion, of action and of lived situations" (Lefebvre, 1991:42). Their site might no longer be exclusively the book, but the 'box', the author might have become the director, and the activity of reading might have been substituted by that of viewing, but television merely competes with the older medium in the same spatial arena. After all, does not the viewer in front of the television screen in his 'den' expect the same as the reader from his book? Are not the romantic novels which so influenced Madame Bovary today's soap operas, and the fashion of blue waist-coats and yellow trousers which took Europe by storm after Goethe's Werther was such a success in the hands of Dynasty's syndicated clothes-outlet? And does the cherished and much admired writer, the hero of so many Russian 19th century plays, not have a twin in the pop-idol of the ilk of Michael Jackson today? Even the library shelves are good for video tapes and many a private citizen is a proud owner albeit not of a bibliotheque but a videoteque.

To be sure, many scholars and critics usually regard the difference between the medium of printing and television and between the activities of reading and viewing sufficient to warrant separate investigations on the level of content. However, what is being re-territorialized under the influence of the new technology is the space in rather than of the story and what is at stake is the "literary

12 As textual as well as visual records show, reading was associated not only with a feminine sphere and hence seen as intensely private because of its seductive aspect but it was also regarded as a ludic occupation. Playfulness, however, unfolds only in intimate small groups rather than in public displays.

13 I am thinking here mainly of thab Hassan's (1982) definitions. As the literature on the features of postmodernism is considerable, the reader is referrod to onc of the more intelligent overviews of the debate provided by Astradur Eysteinsson (1990). 
field' hitherto circumscribed by the 'great tradition'. When postmodernists quarry existing texts (Borges' universe as library, Pynchon's heritage of a certain Inverarity, and Coetzee's explorations of the possibilities or rather impossibilities of re-writing the colonial past) they provide an allegory of the demise of that field albeit within the same literary space produced and inhabited for so long. What is erased on the level of represented space are the distinctions between the library and the world, between meaning and significance, and between event and story, while on the level of representational space the site of the author, the book and the reader is still intact. After all, the critic (and neither authors nor readers/viewers) have changed their loci and their actual relations even in postmodernism. What ought to make literary critics who have naturalized their object together with the space of Literature more than a little nervous, though, is the appearance of allegory in its contemporary sense ${ }^{14}$ as a figure which dominates these texts as a manifestation of an order of signification which is about to disappear. Already the space of Literature together with its technological substitute, television, is being re-territorialized in other domains: the public space of advertising, telecommunication and the encounter group.

In other words, what is at stake is not so much the replacement of reading by viewing or the novel by the TV-drama, something commonly lamented by many critics, but the production of entirely different spaces effecting or making possible the attainment of those goals usually associated with literature in general and the book in particular. Not only are the borders between the public and private and between text and margin increasingly blurred, but the domain of advertising, telecommunication networks and even encounter groups is all embracing. For in the age of information and soundbites the 'here and now' of the Homeric story or the tale contained between the covers of a book is dispersed into an unlimited flow of virtual reality, incapable of producing meaning; contemplation, self-realization and council are no longer to be had from the novel but sought elsewhere. Besides, neither advertising with its promise of wishfulfilment nor the personal computer and its link with satellite-access to the most far flung comers of the world provide the space for an author whose site is being re-territorialized by the anonymous copy-writer and the creators of soft-ware packages. The qualities and effects associated with Literature and even with story-telling arising both from the text and the place of reading/telling/viewing as well as the associated company or even solitude are largely located in other social spaces like sportsfields, holidayresorts and religious or psychological areas of retreat. Meaning and seduction no

14 I refer here to the use of the figure at the hands of Benjamin in his The Origin of German Tragic Drama (1974:354) which has become a much applied term in poststructuralist criticism, nowadays after Paul de Man's Allegories of Reading (1979). 
longer arise from the pages of a novel but from advertising which inscribes itself everywhere. The encounter-group has usurped the space of self-realization; and the laboratory rather than the library has become the most highly regarded site of knowledge production. Transference between imagined and real worlds via the tale or the book seems no longer necessary there where virtual reality via the network appears to be the only 'reality' for readers/viewers snatching bits of tales between switching channels or on their way to work. Where the story-teller is no longer venerated and where the book no longer marks a prized possession, the page seems to hold no more enchantment of a past and the possibility of its reconstruction, as it did for Proust; any heritage may, then, be either up for auction as Lot 49 or appear as questionable 'foe'; and the space of the actual library becomes the archive at the moment of its expansion into a universe (Borges) via telecommunication, where the touch of a button makes available all the world's information.

The republic of letters is shrinking and its domain, the library, is turning into an archive not because more people watch soap-operas instead of reading books and Literature (with capital L), but because the 'global village' blurs all distinctions of time and place. It is the critic eager to hold onto an historically conditioned and delimited domain of Literature by upholding the tenuous link between author, book, and reader as single fixed entities who seems just a little ignorant about the fact that his cherished corpus of works is fast turning into a corpse. It is the critic who will have to decide if he wants to become the guardian of the archive or intervene in the incessant virtual flow of piecemeal information by constructing a new space for the stories which are our actual life.

\section{References}

Bachelard, Gaston. 1969. Poetics of Space. Transl. Mariea Jolas. Boston : Beacon.

Bakhtin, M.M. 1981. The Dialogue Imagination. Ed. Michael Holquist. Transl. Caryl Emerson and Michael Holquist. Austin : University of Texas Press.

Barthes, Roland. 1953. Le degré zéro de l'écriture. Paris : Editions du Seuil.

Barthes, Roland. 1984. The Rustle of Language. Transl. Richard Howard. Oxford : Blackwell.

Benjamin, Walter. 1968. Illuminations. Ed. and with an Introduction by Hannah Arendt. Transl. Harry Zohn. New York : Harcourt, Brace \& World, Inc.

Benjamin, Walter. 1974. Gesammelte Schriften. Bd. I.1. Frankfurt am Main : Suhrkamp.

Blanchot, Maurice. 1982. The Space of Literature. Transl. Ann Smock. Lincoln, London : University of Nebraska Press.

Borges, Jorge Luis. 1970. Labyrinths. Harmondsworth, Middlesex : Penguin.

Chartier, Roger. 1989. The History of Private Lives III. Passions of the Renaissance. Transl. Arthur Goldhammer. Cambridge, Mass. : The Belknap Press at Harvard University Press.

Coetzee, J.M. 1986. Foe. Johannesburg : Ravan. 
De Man, Paul. 1979. Allegories of Reading. New Haven and London : Yale University Press.

De Man, Paul. 1986. The Resistance to Theory. Manchester : Manchester University Press.

Derrida, Jacques. 1992. Acts of Literature. Ed. Derek Attridge. London : Routledge, Chapman and Hall, Inc.

Eysteinsson, Astradur. 1990. The Concept of Modermism. Ithaca and London : Comell University Press.

Flaubert, Gustave. 1976. Bouvard and Pécuchet. Transl. A.J. Kralsheimer. Hardmondsworth, Middlesex : Penguin.

Foucault, Michel. 1966. Les mots et les choses. Paris : Gallimard.

Geertsema, Johan. 1993. Fictionalization, Conscientization and the Trope of Exile in Amandla and Third Generation. Literator, 14(3):109-128, November.

Hassan, Ihab. 1982. The Dismemberment of Orpheus: Toward a Postmodern Literature, 2nd ed. Madison : University of Wisconcin Press.

Hauser, Arnold. 1962. The Social History of Act III. Rococo, Classicism and Romanticism. Transl. Stanley Godman. London and Henley : Routledge \& Kegan Paul.

Homer. 1965. The Odyssey of Homer. Transl. and intro. Richmond Lattimore. New York: Harper Collins.

Lefebvre, Henry. 1991. The Production of Space. Transl. Donal Nicholson-Smith. Oxford : Basil Blackwell.

Levi-Strauss, Claude. 1974. The Savage Mind. London : Weidenfeld \& Nicholson.

Montaigne, Michel de. 1928. The Essays of Michael Lord of Montaigne. Transl. John Florio and with an Introduction by Desmond MacCarthy. Vol. II. London and Toronto : J.M. Dent and Sons.

Nethersole, R. 1990. From Temporality to Spaciality: Changing Concepts in Literary Criticism. Proceedings of the I2th Congress of the ICLA. Munich : ludicium. Vol. 5:5965 .

Nethersole, R. 1991. "Local is lekker": Or Why the New South African Parochialism Will Not Do. Journal of Literary Studies, 7(3/4):239-251, December.

Nietzsche, Friedrich. 1980. Sämtliche Werke. Kritische Studienausgabe Bd.14. München. Berlin : dtv.

Proust, Marcel. 1981. A la recherche du temps perdu. Vol. I: Swann's Way. Within a Budding Grove. Transl. C.K. Scott Moncrieff and Terence Kilmartin. London : Chatto \& Windus.

Pynchon, Thomas. 1965. The Crying of Lot 49. London : Jonathan Cape.

Searle, John R. 1969. Speech Acts. An Essay in the Philosophy of Language. London Cambridge University Press.

Serres, Michel. 1982. Hermes, Literature, Science, Philosophy. Ed. Josuä V. Harari and David Bell. Baltimore : Johns Hopkins University Press.

Thom, René. 1985. From Icon to Symbol. In: Semiotics. An Introductory Reader. Ed. Robert Innis. Bloomington : Indiana University Press. pp. 274-291.

Todorov, Tzvetan. 1990. Genres of Discourse. Transl. Catherine Porter. Cambridge : Cambridge University Press. 
